\title{
Metabolic Changes in Thiobacillus denitrificans Accompanying the Transition from Aerobic to Anaerobic Growth in Continuous Chemostat Culture
}

\author{
By PAULINE JUSTIN AND D. P. KELLY \\ Department of Environmental Sciences, University of Warwick, Coventry CV4 $7 \mathrm{AL}$
}

(Received 4 January 1978; revised 7 March 1978)

Thiobacillus denitrificans grew exclusively aerobically in thiosulphate-limited chemostat culture at all dissolved oxygen concentrations between 12 and $216 \mu \mathrm{M}$. Nitrate reduction did not occur in aerobic cultures and nitrate and nitrite reductases only reached high levels under complete anaerobiosis. Growth yield was greatest $[11.50 \mathrm{~g}$ dry wt (mol thic sulphate oxidized $)^{-1}$ ] at the lowest dissolved oxygen concentration $(12 \mu \mathrm{M})$ and decreased at higher dissolved oxygen concentrations, indicating oxygen to be a growth-inhibitory substrate; the anaerobic yield was only $77 \%$ of the maximum aerobic yield (all tested at a dilution rate of $0.08 \mathrm{~h}^{-1}$ ) in agreement with thermodynamic calculations. Low activities of thiosulphateoxidizing enzyme and sulphur-oxidizing enzyme were detected in aerobic cultures, but activities were even lower in anaerobic cultures. Efficient energy coupling mechanisms with respect to sulphur and thiosulphate oxidations are indicated.

\section{INTRODUCTION}

Thiobacillus denitrificans is the only well-established facultatively anaerobic thiobacillus and is capable of rapid growth on thiosulphate both aerobically and anaerobically with nitrate or nitrite as oxidant (Justin \& Kelly, 1978). No study has been reported on the biochemical and physiological changes in the organism accompanying the transition from aerobic to anaerobic growth conditions. The claim has been made that prolonged aerobic culture results in the loss of capacity to grow anaerobically (Vishniac \& Santer, 1957; Woolley, Jones \& Happold, 1962), but this has never been reliably substantiated. Elsewhere (Eccleston \& Kelly, 1978; Justin \& Kelly, 1978), we have speculated that during aerobic growth of $T$. denitrificans more energy is conserved during thiosulphate oxidation than during growth of other aerobic thiobacilli. The large aerobic growth yield of $T$. denitrificans would be consistent with the conservation of energy during oxidation of the sulphane-sulphur of thiosulphate but not when this is oxidized, for example, by $T$. ferrooxidans (Eccleston \& Kelly, 1978). This could occur if the sulphur-oxidizing oxygenase enzyme found in aerobic thiobacilli (Suzuki, 1965a, b; Suzuki \& Silver, 1966; Charles \& Suzuki, 1966; Silver \& Lundgren, 1968a), which has been postulated to play a central role in sulphane-sulphur oxidation (Kelly, 1968; Roy \& Trudinger, 1969), was not important in aerobic thiosulphate oxidation by $T$. denitrificans. This enzyme could not in any case have a role during anaerobic growth.

\section{METHODS}

Organism, continuous chemostat culture and analytical methods. These were as described previously (Justin \& Kelly, 1978). Dissolved oxygen in chemostat cultures was controlled by varying the composition of the gas phase flowing through the culture: $5 \%(\mathrm{v} / \mathrm{v}) \mathrm{CO}_{2}$ in air was used for fully aerobic cultures, and was progressively supplemented with $5 \%(\mathrm{v} / \mathrm{v}) \mathrm{CO}_{2}$ in $\mathrm{N}_{2}$ so that anaerobic cultures received only the $\mathrm{CO}_{2} / \mathrm{N}_{2}$ 
mixture. Dissolved oxygen was measured with a Clark oxygen electrode and LH Engineering (Slough, Buckinghamshire) dissolved oxygen module, reading dissolved oxygen as a percentage of air saturation. These values were converted to $\mu \mathrm{M}-\mathrm{O}_{2}$ assuming that air-saturated medium contained $245 \mu \mathrm{M}-\mathrm{O}_{2}$ (Tuovinen \& Kelly, 1972). Each new steady state was established by passing six to eight culture volumes of medium through the vessel at a dilution rate of $0.08 \mathrm{~h}^{-1}$. The input medium usually contained $18.69 \mathrm{~mm}-\mathrm{Na}_{2} \mathrm{~S}_{2} \mathrm{O}_{3}$ and $24 \mathrm{mM}-\mathrm{NaNO}_{3}$ for aerobic thiosulphate- and anaerobic nitrate-limitation, but in some cases $40 \mathrm{mM}-$ $\mathrm{NaNO}_{2}$ or $10 \mathrm{mM}-\mathrm{K}_{2} \mathrm{~S}_{4} \mathrm{O}_{6}$ was used instead of nitrate or thiosulphate, respectively.

Preparation of crude extract for enzyme assays. Organisms were harvested from steady state chemostats by centrifuging at $4{ }^{\circ} \mathrm{C}$, washed with water, recentrifuged and the pellet was stored at $-20^{\circ} \mathrm{C}$ or used immediately for enzyme assay. Organisms were suspended $(25 \%, \mathrm{v} / \mathrm{v})$ in $0.05 \mathrm{M}$-Tris/HCl buffer, pH 7.54 , and passed twice through an Aminco French pressure cell at $140 \mathrm{kPa}$. The broken suspension was centrifuged at $10000 \mathrm{~g}$ for $30 \mathrm{~min}$ at $4{ }^{\circ} \mathrm{C}$ and the supernatant liquid was used for enzyme assays.

Nitrate reductase. Nitrite production from nitrate was measured using NADH as electron donor (Sawhney

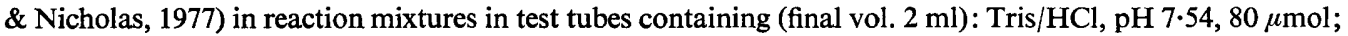
phenazine methosulphate, $1 \mu \mathrm{mol} ; \mathrm{KNO}_{3}, 1 \mu \mathrm{mol}$; crude extract, $0.01 \mathrm{ml}$. After equilibration at $30^{\circ} \mathrm{C}$ for $2 \mathrm{~min}$, the reaction was initiated by adding $1 \mu \mathrm{mol} \mathrm{NADH}$, and terminated after $15 \mathrm{~min}$ by adding $0.1 \mathrm{ml}$ $1 \mathrm{M}$-acetaldehyde and $0.03 \mathrm{mg}$ alcohol dehydrogenase in $0.1 \mathrm{ml} 0.05 \mathrm{M}$-Tris $/ \mathrm{HCl}, \mathrm{pH} 7.54$, to oxidize the residual NADH. Nitrite was determined by the Griess-Ilosvay method (Justin \& Kelly, 1978). Activity was expressed as $\mathrm{nmol} \mathrm{NO}_{2}^{-}$produced $\mathrm{min}^{-1}$ (mg protein) ${ }^{-1}$.

Nitrite reductase. Activity was measured at $30^{\circ} \mathrm{C}$ in $10 \mathrm{ml}$ Warburg flasks (Aminuddin \& Nicholas, 1973)

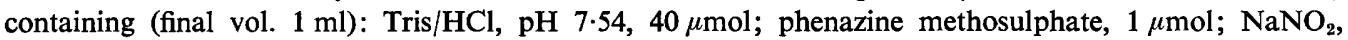
$0.6 \mu \mathrm{mol}$; crude extract, $0.01 \mathrm{ml}$. The reaction was initiated by adding $1 \mu \mathrm{mol} \mathrm{NADH}$, after flushing the flasks with $\mathrm{O}_{2}$-free $\mathrm{N}_{2}$ for $10 \mathrm{~min}$. The reaction was terminated after $0,3,6$ or $10 \mathrm{~min}$ as for nitrate reductase assays and nitrite was estimated. Activity was expressed as $\mathrm{nmol} \mathrm{NO}_{2}^{-}$reduced $\mathrm{min}^{-1}(\mathrm{mg} \text { protein })^{-1}$.

Thiosulphate-oxidizing enzyme. Ferricyanide reduction (Trudinger, 1961) was measured spectrophotometrically with a reaction mixture in $1 \mathrm{~cm}$ cuvettes containing (final vol. $3 \mathrm{ml}$ ): potassium phthalate buffer, pH 5.0, $300 \mu \mathrm{mol} ; \mathrm{Na}_{2} \mathrm{~S}_{2} \mathrm{O}_{3}, 30 \mu \mathrm{mol}$; potassium ferricyanide, $3 \mu \mathrm{mol}$; crude extract, $0.05 \mathrm{ml}$. Thiosulphate and ferricyanide were omitted from the reference cuvette. The reaction was initiated by adding the extract. Activity was measured for up to $60 \mathrm{~min}$ and expressed as $\mu \mathrm{mol}$ ferricyanide reduced $\mathrm{min}^{-1}$ (mg protein) ${ }^{-1}$.

Sulphur-oxidizing enzyme. This was assayed by measuring thiosulphate production and oxygen uptake using Warburg manometers (Suzuki \& Silver, 1966) and reaction mixtures containing (final vol. $2 \mathrm{ml}$ ): Tris/ $\mathrm{HCl}, \mathrm{pH} 7 \cdot 8,500 \mu \mathrm{mol}$; sulphur (BDH 'Optran' grade), $48 \mathrm{mg} ; 2,2$ '-bipyridyl, $0.2 \mu \mathrm{mol}$; catalase, $250 \mu \mathrm{g}$; crude extract, $0 \cdot 1 \mathrm{ml}$. The reaction in air-filled flasks was initiated by adding $5 \mu \mathrm{mol}$ reduced glutathione. After $210 \mathrm{~min}$, during which oxygen uptake was recorded, flask contents were sampled and thiosulphate was determined cyanolytically as ferric thiocyanate (Suzuki, 1965a).

Anaerobic nitrite reduction by suspensions of Thiobacillus denitrificans. From steady state cultures held at different dissolved oxygen concentrations, $200 \mathrm{ml}$ samples were removed and the organisms were harvested by centrifuging, washed and resuspended in salts solution lacking thiosulphate and nitrate. Suspensions in Universal bottles sealed with Suba-seal vaccine stoppers were made anaerobic by passage of $\mathrm{N}_{2}$ and incubated at $30^{\circ} \mathrm{C} . \mathrm{Na}_{2} \mathrm{~S}_{2} \mathrm{O}_{3}\left(2 \mu \mathrm{mol} \mathrm{ml}^{-1}\right)$ and $\mathrm{NaNO}_{2}\left(1.8 \mu \mathrm{mol} \mathrm{ml}^{-1}\right)$ were added and samples were removed for thiosulphate and nitrite analysis at intervals for $300 \mathrm{~min}$.

\section{RESULTS}

\section{Effect of dissolved oxygen concentration on biomass, substrate consumption and yield in steady state chemostats}

Using chemostat cultures at a fixed dilution rate of $0.08 \mathrm{~h}^{-1}$ with a medium containing about 19 mM-thiosulphate and about $24 \mathrm{~mm}$-nitrate, a series of steady states was established at different dissolved oxygen concentrations. The consequence of progressively decreasing the steady state dissolved oxygen from $88 \%$ of air saturation $\left(216 \mu \mathrm{M}-\mathrm{O}_{2}\right)$ in a fully aerobic culture to $5 \%$ of air saturation $\left(12 \mu \mathrm{M}-\mathrm{O}_{2}\right)$ was to increase the steady state biomass without decreasing consumption of the limiting nutrient, thiosulphate, which was completely consumed at all dissolved oxygen concentrations. Consequently the yield increased with decreasing steady state dissolved oxygen, while the specific rate of thiosulphate oxidation $\left(q_{\mathrm{s}_{2} \mathrm{O}_{3}}\right)$ decreased (Table 1). At all dissolved oxygen concentrations tested, there was no significant reduction of nitrate, although trace amounts of nitrite were possibly formed at 12 to $22 \mu \mathrm{M}$ (Table 1). The change from $12 \mu \mathrm{M}-\mathrm{O}_{2}$ to nitrate-limited anaerobiosis resulted in 
Table 1. Effect of dissolved oxygen concentration on biomass, substrate consumption and yield in steady state chemostat cultures of Thiobacillus denitrificans at $D=0.08 h^{-1}$

Growth yields are expressed as $\mathrm{g}$ dry wt (mol thiosulphate oxidized) ${ }^{-1}$ and specific rates of thiosulphate oxidation $\left(q_{\mathrm{s}_{2} \mathrm{O}_{3}}\right)$ as mmol $(\mathrm{g} \text { dry wt })^{-1} \mathrm{~h}^{-1}$.

Dissolved oxygen concn

$\begin{array}{cc}\begin{array}{c}\text { Biomass } \\ \left(\text { mg dry wt 1 }^{-1}\right)\end{array} & \begin{array}{c}\text { Thiosulphate } \\ \text { consumed } \\ \left(\text { mmol l-1 }^{-1}\right)\end{array} \\ 155 & 18.69 \\ 145 & 18.69 \\ 165 & 18.69 \\ 175 & 18.69 \\ 182 & 18.69 \\ 175 & 18.69 \\ 200 & 18.69 \\ 205 & 18.69 \\ 215 & 18.69 \\ 150 & 16.06\end{array}$

Growth
yield
$8 \cdot 29$
$7 \cdot 76$
$8 \cdot 83$
$9 \cdot 36$
$9 \cdot 74$
$9 \cdot 36$
$10 \cdot 70$
$10 \cdot 97$
$11 \cdot 50$
$9 \cdot 33$

$\begin{array}{rcc}q_{\mathrm{s}_{2} \mathrm{O}_{3}} & \begin{array}{c}\text { Nitrate } \\ \text { consumed } \\ \left(\mathrm{mmol} \mathrm{1}^{-1}\right)\end{array} & \begin{array}{c}\text { Nitrite } \\ \text { produced } \\ \left(\text { mmol 1 }^{-1}\right)\end{array} \\ 9.65 & 0 & 0.015 \\ 10.31 & 0 & 0.020 \\ 9.06 & 0 & 0.013 \\ 8.54 & 0 & 0.012 \\ 8.22 & 0 & 0.011 \\ 8.54 & 1 \cdot 1 & 0.021 \\ 7.48 & 0 & 0.030 \\ 7.29 & 0 & 0.117 \\ 6.95 & 0 & 0.156 \\ 8.56 & 23.4 & 0.171\end{array}$

immediate nitrate reduction and transitory accumulation of sulphur and nitrite within $4 \mathrm{~h}$. When the steady state was established, sulphur was absent and nitrite negligible, although, as expected, about $2.6 \mathrm{~mm}$-thiosulphate remained unconsumed (Table 1). Re-aerating the anaerobic culture to establish $80 \%$ air saturation concentrations of $\mathrm{O}_{2}$ resulted in complete consumption of thiosulphate and suppression of nitrate reduction.

\section{Nitrite reduction by suspensions of organisms grown with different concentrations of dissolved oxygen}

Organisms harvested from steady states held at 11 different dissolved oxygen concentrations were tested for their ability to reduce nitrate or nitrite anaerobically in the presence of thiosulphate. Only organisms grown fully anaerobically in nitrate-limited culture showed any nitrate reduction activity. Organisms from cultures held at $68 \%$ air saturation $(167$ $\left.\mu \mathrm{M}-\mathrm{O}_{2}\right)$ and above did not reduce nitrite anaerobically during $5 \mathrm{~h}$ incubation at $30^{\circ} \mathrm{C}$. Organisms grown at lower dissolved oxygen concentrations reduced nitrite after a lag, the length of which was a function of the dissolved oxygen regime in the culture from which the organisms were harvested (Fig. 1). There was no lag with organisms grown anaerobically with nitrate-limitation.

\section{Nitrate and nitrite reductase activities}

These were assayed in crude extracts using NADH as reductant. Activities of both enzymes were negligible in cultures maintained at dissolved oxygen concentrations equivalent to $52 \%$ air saturation $\left(127 \mu \mathrm{M}-\mathrm{O}_{2}\right)$ and above (Table 2). Nitrate reductase increased slightly below $54 \mu \mathrm{M}-\mathrm{O}_{2}$ and to 10 times the aerobic level under complete anaerobiosis. Nitrite reductase activity increased considerably as the dissolved oxygen concentration was lowered from 91 to $14 \mu \mathrm{M}-\mathrm{O}_{2}$, but rose to very high levels in anaerobic cultures (Table 2). Using freshly harvested anaerobic organisms assayed soon after breakage in the French pressure cell, the maximum nitrate reductase activity was $28.6 \mathrm{nmol} \mathrm{min}^{-1}(\mathrm{mg} \text { protein) })^{-1}$ and nitrite reductase activity was $264 \cdot 0 \mathrm{nmol} \mathrm{m^{-1 }}$ (mg protein) ${ }^{-1}$.

Both enzymes were reasonably stable when stored at $-20^{\circ} \mathrm{C}$. Nitrate reductase was not raised above its aerobic levels in anaerobic organisms cultured in nitrate-free nitrite-limited medium, but nitrite reductase reached a level comparable to that under nitrate-limited anaerobiosis (Table 2). Substituting tetrathionate for the usual thiosulphate substrate (Justin \& Kelly, 1978) under anaerobic nitrate-limitation resulted in enzyme activities comparable to those in thiosulphate cultures (Table 2). 


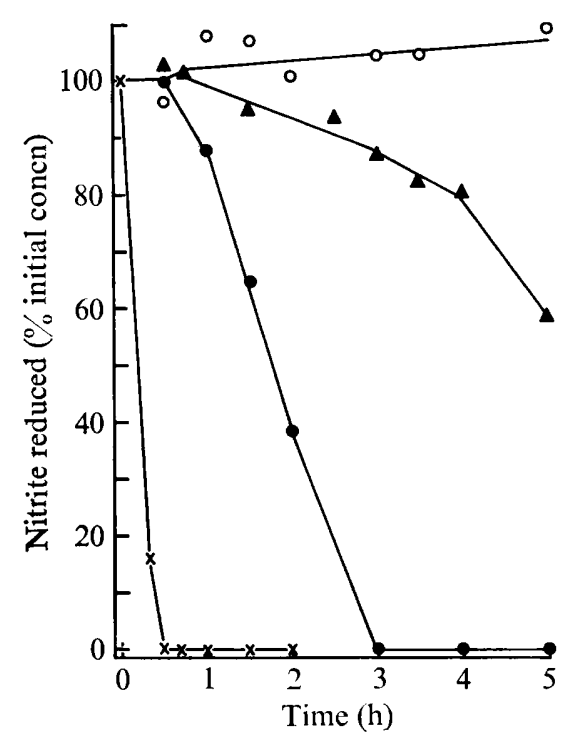

Fig. 1. Nitrite reduction by anaerobic suspensions of Thiobacillus denitrificans taken from chemostat cultures grown with different concentrations of dissolved oxygen. Consumption of nitrite, in the presence of $2 \mathrm{~mm}-\mathrm{Na}_{2} \mathrm{~S}_{2} \mathrm{O}_{3}$, is expressed as a percentage of the initial nitrite concentration $\left(1.8 \mathrm{mM}-\mathrm{NaNO}_{2}\right)$. Steady state oxygen concentrations in the cultures from which the bacteria were taken were $216 \mu \mathrm{M}(\bigcirc), 135 \mu \mathrm{M}(\Delta), 74 \mu \mathrm{M}(\bullet)$ and $0(\times)$.

Table 2. Effect of dissolved oxygen concentration on nitrate and nitrite reductase activities in crude extracts of Thiobacillus denitrificans from chemostat cultures at $D=0.08 h^{-1}$

$\begin{gathered}\text { Dissolved } \\ \text { oxygen } \\ \text { concn } \\ (\mu \mathrm{M})\end{gathered}$
211
176
147
127
91
86
54
15
14
0
0
0

\begin{tabular}{|c|c|c|}
\hline \multirow[b]{2}{*}{ Growth-limiting substrate } & \multicolumn{2}{|c|}{$\begin{array}{c}\text { Enzyme activity } \\
{\left[\text { nmol } \text { min }^{-1}(\text { mg protein })^{-1}\right]}\end{array}$} \\
\hline & $\begin{array}{l}\text { Nitrate } \\
\text { reductase }\end{array}$ & $\begin{array}{l}\text { Nitrite } \\
\text { reductase }\end{array}$ \\
\hline Thiosulphate & 1.6 & $1 \cdot 2$ \\
\hline Thiosulphate & $1 \cdot 3$ & $1 \cdot 3$ \\
\hline Thiosulphate & $1 \cdot 3$ & 0 \\
\hline Thiosulphate & $1 \cdot 7$ & 0 \\
\hline Thiosulphate & $1 \cdot 2$ & $29 \cdot 4$ \\
\hline Thiosulphate & $1 \cdot 6$ & $61 \cdot 7$ \\
\hline Thiosulphate & $2 \cdot 2$ & $48 \cdot 5$ \\
\hline Thiosulphate & $4 \cdot 0$ & 85.9 \\
\hline Thiosulphate & $9 \cdot 0$ & $47 \cdot 4$ \\
\hline Nitrate & $18 \cdot 9$ & $269 \cdot 0$ \\
\hline Nitrite & $2 \cdot 0$ & $280 \cdot 0$ \\
\hline (nitrate-free medium) & & \\
\hline $\begin{array}{c}\text { Nitrate } \\
\left(\mathrm{K}_{2} \mathrm{~S}_{4} \mathrm{O}_{6} \text { instead of } \mathrm{Na}_{2} \mathrm{~S}_{2} \mathrm{O}_{3}\right)\end{array}$ & $15 \cdot 8$ & $241 \cdot 0$ \\
\hline
\end{tabular}

\section{Sulphur-oxidizing enyzme}

Activities of this enzyme were very low although it was detected in both anaerobic and aerobic organisms (Table 3). In most cases the molar ratio of $\mathrm{O}_{2}$ consumed to thiosulphate formed was about $1 \cdot 0$, as required by the mechanism proposed by Suzuki $(1965 a, b)$ and Suzuki \& Silver (1966). Freshly prepared crude extracts from freshly harvested aerobic $\left(80 \%\right.$ air saturation, $196 \mu \mathrm{M}-\mathrm{O}_{2}$ ) and anaerobic cultures gave activities of 1.069 and 0.228 $\mu$ mol thiosulphate formed $(210 \mathrm{~min})^{-1}(\mathrm{mg} \text { protein })^{-1}$, respectively. The activity in crude extracts declined as the dissolved oxygen content of the cultures was lowered (Table 3 ). Mean values for six aerobic cultures $\left(127\right.$ to $\left.211 \mu \mathrm{M}-\mathrm{O}_{2}\right)$ and four anaerobic cultures were 
Table 3. Effect of dissolved oxygen concentration on sulphur-oxidizing enzyme activity in crude extracts of Thiobacillus denitrificans from chemostat cultures at $D=0.08 \mathrm{~h}^{-1}$

\begin{tabular}{|c|c|c|c|}
\hline \multirow{2}{*}{$\begin{array}{c}\text { Dissolved } \\
\text { oxygen } \\
\text { concn } \\
(\mu \mathrm{M})\end{array}$} & & \multicolumn{2}{|c|}{$\begin{array}{c}\text { Enzyme activity } \\
{\left[\mu \mathrm{mol}(210 \mathrm{~min})^{-1}(\mathrm{mg} \text { protein })^{-1}\right]}\end{array}$} \\
\hline & Growth-limiting substrate & $\begin{array}{l}\text { Oxygen } \\
\text { uptake }\end{array}$ & $\begin{array}{l}\text { Thiosulphate } \\
\text { formation }\end{array}$ \\
\hline 211 & Thiosulphate & 0.42 & 0.44 \\
\hline 176 & Thiosulphate & $0 \cdot 61$ & $0 \cdot 63$ \\
\hline 147 & Thiosulphate & 0.50 & $0 \cdot 31$ \\
\hline 127 & Thiosulphate & $0 \cdot 39$ & 0.92 \\
\hline 91 & Thiosulphate & 0.47 & $0 \cdot 45$ \\
\hline 86 & Thiosulphate & $0 \cdot 51$ & $0 \cdot 24$ \\
\hline 54 & Thiosulphate & $0 \cdot 28$ & $0 \cdot 11$ \\
\hline 22 & Thiosulphate & $0 \cdot 35$ & $0 \cdot 40$ \\
\hline 15 & Thiosulphate & $0 \cdot 31$ & $0 \cdot 36$ \\
\hline 14 & Thiosulphate & $0 \cdot 14$ & $0 \cdot 14$ \\
\hline 0 & Nitrate & $0 \cdot 18$ & $0 \cdot 17$ \\
\hline 0 & $\begin{array}{l}\text { Nitrite } \\
\text { (nitrate-free medium) }\end{array}$ & $0 \cdot 41$ & $0 \cdot 16$ \\
\hline 0 & $\begin{array}{c}\text { Nitrate } \\
\left(\mathrm{K}_{2} \mathrm{~S}_{4} \mathrm{O}_{6} \text { instead of } \mathrm{Na}_{2} \mathrm{~S}_{2} \mathrm{O}_{3}\right)\end{array}$ & $0 \cdot 76$ & $0 \cdot 25$ \\
\hline
\end{tabular}

$0.740 \pm$ S.E.M. $0 \cdot 32$ and $0.202 \pm 0.038 \mu \mathrm{mol}(210 \mathrm{~min})^{-1}(\mathrm{mg} \text { protein })^{-1}$. Activity was dependent on the presence of both cell-free extract and reduced glutathione. In one test with an aerobic extract, $1.20 \mu \mathrm{mol}$ thiosulphate was formed by the complete assay mixture and $0.27 \mu \mathrm{mol}$ in the absence of glutathione, indicating some glutathione-independent activity, perhaps comparable with that studied by Taylor (1968) in T. neapolitanus.

\section{Thiosulphate-oxidizing enzyme}

This was detected in all steady state cultures, but in two freshly harvested and assayed aerobic cultures $\left(196 \mu \mathrm{M}-\mathrm{O}_{2}\right)$ activities were 0.144 and $0.112 \mu \mathrm{mol}$ ferricyanide reduced $\mathrm{min}^{-1}$ $(\mathrm{mg} \text { protein })^{-1}$, whereas activity in a comparable anaerobic culture was only 0.018 . Activity was typically 0.012 to 0.02 in all anaerobic cultures. Activity was gradually lost on storage at $-20{ }^{\circ} \mathrm{C}$. These low activities should be compared with typical crude extract activities [ $\mu$ mol ferricyanide reduced $\mathrm{min}^{-1}$ (mg protein) ${ }^{-1}$ ] of 4.97 for T. neapolitanus (Kelly, 1966), 9.00 for T. ferrooxidans (Silver \& Lundgren, 1968b) and 0.96 for T. thioparus (Lyric \& Suzuki, 1970).

\section{DISCUSSION}

The mechanism of sulphur-compound-dependent nitrate reduction in $T$. denitrificans is basically similar to that in other anaerobic nitrate-reducing bacteria (Adams, Warnes \& Nicholas, 1971; Ishaque \& Aleem, 1973; Baldensperger \& Garcia, 1975; Sawhney \& Nicholas, 1977). However, the regulation of the system under aerobic and anaerobic conditions has not previously been reported. Our experiments demonstrate that the levels of nitrate and nitrite reductase are regulated in response to oxygen tension, significant activities of nitrate reductase being detected only in microaerophilically and anaerobically cultured bacteria. Nitrite reductase was detected in cultures grown with $91 \mu \mathrm{M}-\mathrm{O}_{2}$ but not with $127 \mu \mathrm{M}-$ $\mathrm{O}_{2}$. For both enzymes, maximum activity was only found under complete anaerobiosis. Although nitrate and nitrite reductases were found in cultures held under low oxygen steady states, no nitrate reduction was detected in the cultures, indicating that oxygen is also inhibitory to nitrate reduction. Nitrate reductase synthesis also required the presence of nitrate, since cultures grown anaerobically with nitrite did not form significant nitrate reductase. These findings contrast with the metabolically similar Thiomicrospira denitrificans, in which nitrate reductase is constitutive (Timmer-ten-Hoor, 1977). The similar levels of nitrite 
reductase found in anaerobic nitrate- or nitrite-limited chemostats suggested that this enzyme was fully derepressed under all the growth conditions tested.

The two enzymes possibly concerned in sulphur compound oxidation, the thiosulphateand sulphur-oxidizing enzymes, were present at relatively very low levels in aerobic $T$. denitrificans and were repressed by 70 to $90 \%$ during anaerobic growth. The activity of thiosulphate-oxidizing enzyme in anaerobic cultures was only $0.3 \%$ of that in some aerobic thiobacilli (Kelly, 1966; Silver \& Lundgren, 1968b) but similar to that in aerobic Thiobacillus A2 (Kelly, 1973). Earlier, Trudinger (personal communication) was unable to detect this enzyme in a different strain of $T$. denitrificans. The activity of the glutathione-dependent sulphur-oxidizing enzyme was maximally around $1 \mu \mathrm{mol}$ sulphur oxidized per mg protein in $210 \mathrm{~min}$. This is of the same order as found for T. thiooxidans, T. thioparus and T. ferrooxidans (Suzuki, 1965a, $b$; Suzuki \& Silver, 1966; Silver \& Lundgren, 1968a) but is a very low activity. The organisms growing aerobically at a dilution rate of $0.08 \mathrm{~h}^{-1}$ oxidized thiosulphate at a rate of $10.3 \mathrm{mmol}(\mathrm{g} \text { dry wt})^{-1} \mathrm{~h}^{-1}$. The protein content of aerobic bacteria was approximately $50 \%(\mathrm{w} / \mathrm{w})$ of the dry wt, so the $q_{\mathrm{s}_{2} \mathrm{O}_{3}}$ was equivalent to $20.6 \mu \mathrm{mol}(\mathrm{mg}$ total protein) ${ }^{-1} h^{-1}$, or a rate some 80 times more rapid than could be accounted for by sulphur-oxidizing enzyme oxidation of the sulphane-sulphur of thiosulphate. We must conclude that our results do not support the view that the sulphur-oxidizing enzyme can be involved in thiosulphate metabolism in T. denitrificans. There is, moreover, no obvious role for the enzyme activity observed in anaerobic bacteria, unless this enzyme has another, as yet undetected, function.

Thiobacillus denitrificans can be switched back and forth in the chemostat between aerobic and anaerobic growth with no permanent loss of nitrate-reducing capacity during aerobiosis. It appears, however, that oxygen is an inhibitory substrate as aerobic growth yields increased progressively as the dissolved oxygen concentration was lowered. At the lowest oxygen level $(12 \mu \mathrm{M})$, the yield was 60 to $70 \%$ greater than that with $200 \mu \mathrm{M}-\mathrm{O}_{2}$. The yield at $12 \mu \mathrm{M}-\mathrm{O}_{2}$ of $11.50 \mathrm{~g}$ dry wt per mol thiosulphate oxidized should be compared with the anaerobic yield, at the same dilution rate, of $9 \cdot 33$. Calculated as yield per mol thiosulphate oxidized for energetic purposes (Justin \& Kelly, 1978), these values become 14.88 and 11.44 respectively, i.e. the anaerobic yield is $76.9 \%$ of the aerobic yield. This may be compared with $71 \%$ for relative $Y_{\mathfrak{a}}$ values and $79 \cdot 2 \%$ for theoretically available energy (Justin \& Kelly, 1978), and probably indicates that dissolved oxygen at $12 \mu \mathrm{M}$ is optimal for the efficient aerobic growth of $T$. denitrificans. While $T$. denitrificans grows best at low dissolved oxygen concentrations it is still capable of producing greater growth yields at high dissolved oxygen than obligately aerobic thiobacilli (Justin \& Kelly, 1978), probably by virtue of a more efficient energyconserving sulphur oxidation mechanism.

We thank Dr Anje Timmer-ten-Hoor for her thesis and useful discussion. This work was carried out under NERC research grant GR3/2693.

\section{REFERENCES}

Adams, C. A., Warnes, G. M. \& Nicholas, D. J. D. (1971). A sulphite-dependent nitrate reductase from Thiobacillus denitrificans. Biochimica et biophysica acta 235, 398-406.

Aminuddin, M. \& Nicholas, D. J. D. (1973). Sulphide oxidation linked to the reduction of nitrate and nitrite in Thiobacillus denitrificans. Biochimica et biophysica acta 325, 81-93.

BALDENSPERgER, J. \& GARCIA, J.-L. (1975). Reduction of oxidized inorganic nitrogen compounds by a new strain of Thiobacillus denitrificans. Archives of Microbiology 103, 31-36.
Charles, A. M. \& Suzuki, I. (1966). Mechanism of thiosulphate oxidation by Thiobacillus novellus. Biochimica et biophysica acta 128, 510-521.

Eccleston, M. \& Kelly, D. P. (1978). Oxidation kinetics and chemostat growth kinetics of Thiobacillus ferrooxidans on tetrathionate and thiosulphate. Journal of Bacteriology (in the Press).

IshaQue, M. \& AleeM, M. I. H. (1973). Intermediates of denitrification in the chemoautotroph Thiobacillus denitrificans. Archiv für Mikrobiologie 94, 269-282. 
Justin, P. \& Kelly, D. P. (1978). Growth kinetics of Thiobacillus denitrificans in anaerobic and aerobic chemostat culture. Journal of General Microbiology 107, 123-130.

Kelly, D. P. (1966). Fluoroacetate toxicity in Thiobacillus neapolitanus and its relevance to the problem of obligate chemoautotrophy. Archiv für Mikrobiologie 61, 59-76.

Kelly, D. P. (1968). Biochemistry of oxidation of inorganic sulphur compounds by microorganisms. Australian Journal of Science 31, 165-173.

KeLLY, D. P. (1973). Inorganic sulphur metabolism in Thiobacillus A2. In 1st International Congress of Bacteriology, Abstracts II, p. 71. Jerusalem: International Association of Microbiological Societies.

LyRIC, R. M. \& SuzUKI, I. (1970). Enzymes involved in the metabolism of thiosulphate by Thiobacillus thioparus. III. Properties of thiosulphate-oxidizing enzyme and proposed pathway of thiosulphate oxidation. Canadian Journal of Biochemistry 48, 355-363.

Roy, A. B. \& Trudinger, P. A. (1969). The Biochemistry of Inorganic Compounds of Sulphur. Cambridge: Cambridge University Press.

Sawhiney, V. \& Nicholas, D. J. D. (1977). Sulphiteand NADH-dependent nitrate reductase from Thiobacillus denitrificans. Journal of General Microbiology 100, 49-58.

Silver, M. \& Lundgren, D. G. (1968a). Sulfuroxidizing enzyme of Ferrobacillus ferrooxidans (Thiobacillus ferrooxidans). Canadian Journal of Biochemistry 46, 457-461.

Silver, M. \& Lundgren, D. G. (1968b). The thio- sulfate-oxidizing enzyme of Ferrobacillus ferrooxidans (Thiobacillus ferrooxidans). Canadian Journal of Biochemistry 46, 1215-1220.

SuzUKI, I. (1965a). Oxidation of elemental sulfur by an enzyme system of Thiobacillus thiooxidans. Biochimica et biophysica acta 104, 359-371.

SuzUKI, I. (1965b). Incorporation of atmospheric oxygen-18 into thiosulfate by the sulfur-oxidizing enzyme of Thiobacillus thiooxidans. Biochimica et biophysica acta 110, 97-101.

Suzuki, I. \& Silver, M. (1966). The initial product and properties of the sulphur-oxidizing enzyme of thiobacilli. Biochimica et biophysica acta 122, 22-33.

TAYLOR, B. F. (1968). Oxidation of elemental sulfur by an enzyme system from Thiobacillus neapolitanus. Biochimica et biophysica acta 170, 112-122.

TIMMER-TEN-Hoor, A. (1977). Denitrificerende Kleurloze Zwavelbacteriën, p. 81. Doctoral thesis, University of Groningen, The Netherlands.

Trudinger, P. A. (1961). Thiosulphate oxidation and cytochromes in Thiobacillus x. Biochemical Journal 78, 673-686.

Tuovinen, O. H. \& Kelly, D. P. (1972). Biology of Thiobacillus ferrooxidans in relation to the microbiological leaching of sulphide ores. Zeitschrift fïr allgemeine Mikrobiologie 12, 311-346.

Vishniac, W. \& Santer, M. (1957). The thiobacilli. Bacteriological Reviews 21, 195-213.

Woolley, D., Jones, G. L. \& Happold, F. C. (1962). Some metabolic differences between Thiobacillus thioparus, $T$. denitrificans and $T$. thiocyanoxidans. Journal of General Microbiology 29, 311-316. 